\title{
Frequency of Helicobacter Pylori Infection on Histopathology in Patients with Dyspepsia
}

\author{
Shazia Yasir*, Faisal Moin, Syed Mamoon Akhtar \\ Department of Emergency Medicine, Ziauddin University Hospital, North Campus, Karachi \\ *Corresponding author: drshazia24@live.com \\ Received March 28, 2014; Revised April 18, 2014; Accepted May 07, 2014
}

\begin{abstract}
Objective: To determine the frequency of Helicobacter Pylori infection on histopathology in patients presenting with dyspepsia. Background: Helicobacter Pylori is associated with dyspepsia in patients who have gastric mucosal abnormalities and this infection can be diagnosed by invasive and non invasive test. Histology of endoscopically taken biopsy, for exploration of this organism is used in this study. Study Design: Cross-sectional, observational study. Place and Duration of Study: Department of Emergency Medicine, Ziauddin University Hospital, Karachi for Six months from March 2013 to August 2013. Methodology: A total of 362 cases with dyspeptic symptoms were underwent an upper gastrointestinal endoscopy after fulfilling the selection criteria. $\mathrm{H}$. Pylori infection would be defined by the presence of dyspeptic symptoms with detection of the bacterium on histopathology. All the data was collected by using a proforma and different parameters were assessed for a minimum follow-up period of one month. Data was analyzed by descriptive statistics using SPSS software version 19. Result: Out of 362 cases of dyspepsia 218 (60.2\%) males and 144 (39.8\%) females (Male: Female was 1.5: 1). Two fifty one (69.3\%) patients with dyspepsia were H. Pylori positive on histopathology. Out of 251 cases having $\mathrm{H}$. Pylori infection 165 (75.7\%) were male and 86 (59.7\%) female. High percentage was found in the age between 31 50 years, 160 (77.3\%). Conclusion: In this study $69.3 \%$ of the patients examined were $H$. Pylori positive on histopathology. Male sex and older age (> 30 years) are independent risk factor of $H$. Pylori infection in dyspeptic patients.
\end{abstract}

Keywords: dyspepsia, H Pylori, gastric mucosal biopsy, H. Pylori positive gastritis

Cite This Article: Shazia Yasir, Faisal Moin, and Syed Mamoon Akhtar, "Frequency of Helicobacter Pylori Infection on Histopathology in Patients with Dyspepsia.” American Journal of Clinical Medicine Research, vol. 2, no. 3 (2014): 53-56. doi: 10.12691/ajcmr-2-3-1.

\section{Introduction}

In clinical practice, dyspepsia is a common and frequent presenting complaint and there causes are ranging from esophagitis, cholelithiasis, gastroduodenitis and peptic ulcer disease. Upper gastrointestinal endoscopy is the abundance examination in patients with upper gastrointestinal diseases. The symptoms of dyspepsia may be episodic, recurrent or chronic. Symptoms are often associated with eating, but this is not always the case.

Helicobacter Pylori (H. Pylori) infection is a worldwide problem and human beings have been the preferred host colonized for at least 50,000 years and probably throughout their evolution. The organism colonizes from childhood and persists throughout life [1]. It is estimated that about $50 \%$ of the world's population has H. Pylori colonization in the gastric mucosa [2] and it signifies a wide range of differences in the geographic, ethnic and racial differences throughout the world [3]. Extent of infection among developing nations is higher than in industrialized nation $80-90 \%$ Vs $25 \%$ respectively [4], probably due to poor sanitary conditions and standard of hygiene.
H. Pylori is a gram negative bacterium, it survives in water and is considered as a waterborne pathogen for transmission [5] and this provides compelling evidence that it is associated not only with gastro-duodenal diseases, including peptic ulcer diseases $83 \%$, chronic gastritis $93 \%$, gastric adenocarcinoma $6 \%$ and low-grade gastric mucosa-associated lymphoid tissue (MALT) lymphoma and non-cardiac [6,7] but also linked with extra-gut diseases $[8,9]$. Therefore, upper gastrointestinal endoscopy used for exploration of this organism. H. Pylori infection can be diagnosed by invasive and non-invasive tests [10]. The non-invasive tests include serologic tests, Urea Breath Test, and stool antigen assays. The invasive test used in this study is histopathology of the endoscopically taken biopsy, which has a very high sensitivity (96\%) and specificity (98.8\%), even though it requires expertise for interpretation [11]. Histological the prevalence of Helicobacter Pylori infection is $62.07 \%$ in dyspepsia [12]. The endurance potential of $\mathrm{H}$. Pylori in the stomach make it complicated and multi drug regime which is consisting of two antibiotics (usually selected from Tetracycline, Metronidazole, Clarithromycin and Amoxicillin) pooled with acid suppressants and bismuth compound is necessitate for effectual treatment [13]. 
The role of Helicobacter Pylori in inducing dyspepsia is well known and proved. International studies revealed the incident of $\mathrm{H}$. Pylori infection in patients with dyspepsia to be high, ranging of $60.5 \%$ to $73 \%[14,15,16]$ Considering the factors responsible for a relatively high and increasing prevalence of $\mathrm{H}$. Pylori infection in poor countries i-e poverty, overcrowding, and poor hygienic conditions, the expected prevalence of $\mathrm{H}$. Pylori infection associated with dyspepsia in these regions should be relatively high. Local studies on the subject are scarce. This makes a strong basis and rationale for my study to estimate the actual burden of $\mathrm{H}$. Pylori infection.

\section{Methodology}

This study was carried out at the department of emergency medicine, Ziauddin University Hospital, Karachi, Pakistan. All patient with age greater than 18 with either sex, with symptoms of dyspepsia who are non smoker and non alcoholic were included in this study, while patient with previous gastric and duodenal surgery, injection of any antibiotic (including Metronidazole) within 4 weeks, smoker, alcoholics, on steroids therapy due to any cause, unfit for endoscopy or recent myocardial infarction, known case of Zollinger-Ellison syndrome, cholecystitis, cholelithiasis, and chronic liver disease were excluded. A total of 362 patients with dyspeptic symptoms were underwent an upper gastrointestinal endoscopy and $\mathrm{H}$. Pylori infection would be defined by the presence of dyspeptic symptoms with detection of the bacterium on histopathology.

A database was complete using inpatients and outpatients medical records by an independent observer who was not the part of research team and/or inpatient care. Data collection include variable such as frequency of H. Pylori infection with dyspepsia with respect to age, gender, site of biopsy and duration of dyspepsia. All the patients were follow-up for the minimum period of one month. Data was analyzed by descriptive statistics in term of frequencies, percentage and mean (+/-) standard deviation using statistical package for social science (SPSS) software version 19. The P value was collected by independent-sample $\mathrm{T}$-Test and statistical significance was defined as $\mathrm{p}<0.05$. An informed consent was taken from all patient and ethical procedures were followed. Data was delinked for patient identity and due care was taken for confidentially of the records.

\section{Result}

A total of 362 cases of dyspepsia were included in the study. There were 218 (60.2\%) males and 144 (39.8\%) females.

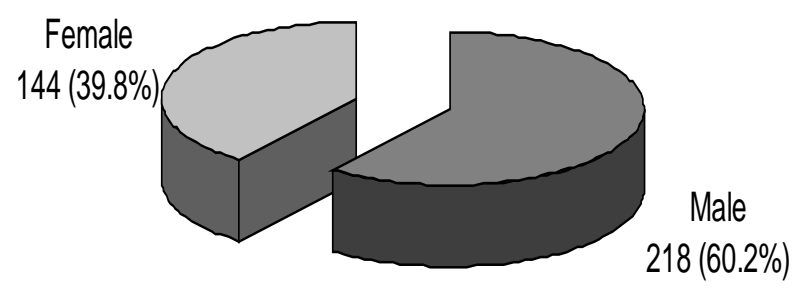

The mean age was $49.19( \pm 13.75)$ years. The age ranged from 20 to 65 years. Majority of cases had age between 31 - 50 years, 207 (57.2\%).

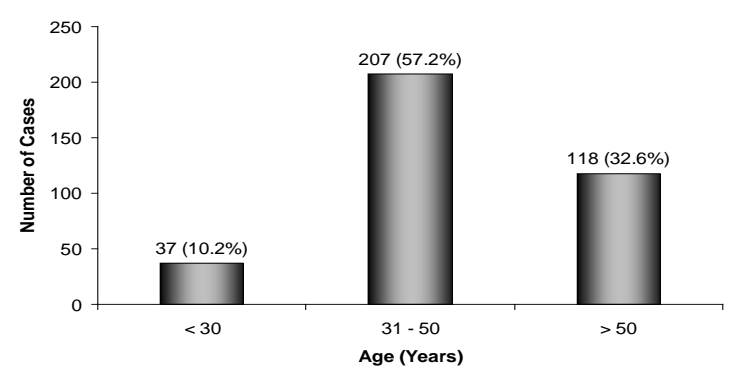

Most of the dyspeptic patients presented with epigastric pain 272(75.1\%) followed by nausea \& vomiting 66 (18.2\%), with heart burn 51 (14.1\%) and 44 (12.2\%) cases were presented with bloating.

\begin{tabular}{|l|c|c|}
\hline \multicolumn{3}{|c|}{ SYMPTOMS OF DYSPEPSIA } \\
\hline Symptoms & \# of Cases & $\%$ \\
\hline Epigastric Pain & 272 & $75.10 \%$ \\
\hline Nausea \& vomiting & 66 & $18.20 \%$ \\
\hline Heart Burn & 51 & $14.10 \%$ \\
\hline Bloating & 44 & $12.20 \%$ \\
\hline
\end{tabular}

Sites of biopsy presented in below table. Out of 362 biopsies; 229 (63.3\%) biopsies taken from gastric antrum and 133 (36.7\%) from Duodenal Mucosa.

\begin{tabular}{|l|c|c|}
\hline \multicolumn{3}{|c|}{ SITE OF BIOPSY } \\
\hline Sites & \# of Cases & $\%$ \\
\hline Gastric antrum & 229 & $63.30 \%$ \\
\hline Duodenal Mucosa & 133 & $36.70 \%$ \\
\hline
\end{tabular}

Patients were considered infected with H. Pylori when bacterium was detected on histopathology. Two fifty one (69.3\%) patients with dyspepsia were H. Pylori positive on histopathology (Figure below).

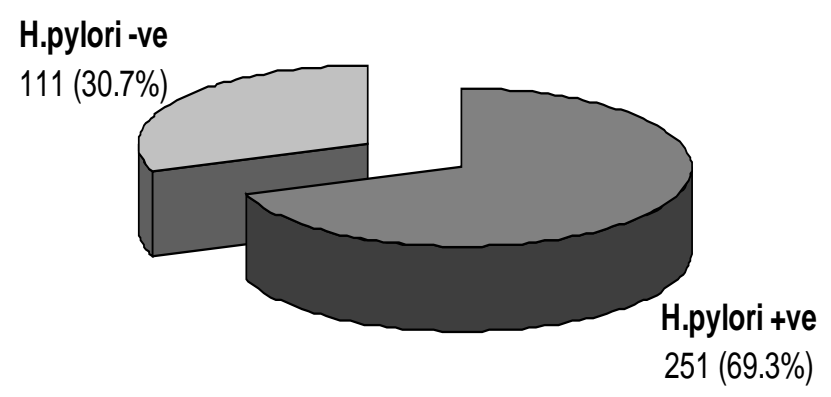

Stratification was done with regards to age, gender and duration of dyspepsia to see effects of these on outcomes. 165 (75.7\%) male while 86 (59.7\%) female had Helicobacter Pylori infection on histopathology. High percentage was found in the age between 31 - 50 years, $160(77.3 \%)$.

\begin{tabular}{|c|c|c|c|}
\hline \multicolumn{4}{|c|}{ WITH RESPECT TO GENDER } \\
\hline Gender & Total & H. Pylori +ve & $\%$ \\
\hline Male & 218 & 165 & $75.70 \%$ \\
\hline Female & 144 & 86 & $59.70 \%$ \\
\hline
\end{tabular}




\begin{tabular}{|c|c|c|c|}
\hline \multicolumn{4}{|c|}{ WITH RESPECT TO AGE } \\
\hline Age (Years) & Total & H.Pylori +ve & \% \\
\hline$<30$ & 37 & 10 & $27.00 \%$ \\
\hline $31-50$ & 207 & 160 & $77.30 \%$ \\
\hline$>50$ & 118 & 81 & $68.60 \%$ \\
\hline
\end{tabular}

High percentage of positive Helicobacter Pylori was seen in patients with dyspeptic symptoms for more than one year, 115 (70.1\%).

\begin{tabular}{|c|c|c|c|}
\hline \multicolumn{4}{|c|}{ WITH RESPECT TO DURATION } \\
\hline Duration & Total & H. Pylori +ve & $\%$ \\
\hline$\leq 1$ (Year) & 198 & 136 & $68.70 \%$ \\
\hline$>1$ (Year) & 164 & 115 & $70.10 \%$ \\
\hline
\end{tabular}

\section{Discussion}

Dyspepsia is a common symptoms vertain by 25 to $40 \%$ of the general year. Dyspepsia comprise a number of upper abdominal complaint like pain and nausea, fullness, discomfort, early satiety, regurgitation, anorexia, blotting, heart burn and bleeding, but is mostly defined as conform or pain in upper abdomen (centered). Helicobacter pylori infection is most likely a cause of dyspepsia, other causes includes microscopic inflammation, motor abnormalities and psychiatric illness.

Helicobacter pylori (H-Pylori)is a gram negative bacilli, spiral in shape and it is one of the most common chronic infection which is associated with preponderance causes of gastric including $90 \%$ of duodenal ulcer and $75 \%$ of gastric ulcer. Studies has shown high incidence of $\mathrm{H}-$ pylori infection associated with dyspepsia in patients who have gastric mucosal abnormalities. Without any endoscopic findings $\mathrm{H}$-pylori have been seen on biopsy specimen. In this stare different studies have been done specially in pediatric group, which shows normal mucosa on endoscopy but the H-pylori was present on biopsy specimen.

Multiple studies on adult conclude that, amongst non ulcer patient's there are high dominance of H-pylori infection. In a persistent long term condition H-pylori infection is correlated with incident and relapse of the peptic ulcer disease which lead to high risk of developing gastric carcinoma. In this study 362 cases of dyspepsia were included. 44(12.2\%) cases were obtained with bloating. This is consistent with results of previous studies conducted in Karachi [12].

In this study $69.3 \%$ of the patients examined were $\mathrm{H}$. Pylori positive on histopathology. This is in agreement with earlier reports from developing countries regarding the prevalence of $\mathrm{H}$. pylori [24,25,26,27,28]. In Kuwait, a study was conducted which shoes $81 \%$ infection rate [24]. $86 \%$ was detected in one study in Jordan [25] and in another study, 82\% infection rate was reported [26]. 145 (74\%) of 196 dyspeptic patients were found infected with H. Pylori, in the Kingdom of Saudi Arabia (KSA) [27]. The prevalence of $\mathrm{H}$. Pylori in Sudanese subjects with gastro duodenal inflammation was $80 \%$ in patients with gastritis and $56 \%$ in patients with duodenal ulcers (DU) [28].

In a prospective survey from south of Iran was reported H. Pylori infection in $67.1 \%$ of 1000 enrolled dyspeptic patients [29]. In Yemen, 82.2\% of 275 dyspeptic patients are H. Pylori-infected [30]. In United Arab Emirates [31] and in Kuwait [32], 90.39\% of 437 and $96.6 \%$ of 204 studied subjects are infected with $\mathrm{H}$. Pylori, respectively. A local study reported that the prevalence of Helicobacter Pylori infection is $62.07 \%$ in dyspepsia histological [12]. In another local study from CMH Rawalpindi the antralbiopsy histopathology of $51 \%$ patients was positive for Helicobacter Pylori infection [33]. Abu Talib et al reported the incidence of $\mathrm{H}$. Pylori in patients with dyspepsia was 82\% [34] while another local study reported the incidence of $\mathrm{H}$ Pylori was 64\% [35]. In this study 165 (75.7\%) male while 86 (59.7\%) female had Helicobacter Pylori infection on histology. High percentage was found in the age between $31-50$ years, 160 (77.3\%). During a study in Rawalpindi, it is reported that $54 \%$ males $(n=67)$ while $41 \%$ female $(n=33)$ had Helicobacter Pylori gastritis on histology [33].

Although, culture is the gold standard to show the presence or absence of Helicobacter Pylori infection but in this study the diagnostic method used was finding of $\mathrm{H}$ Pylori on histopathology of gastric antrum and duodenal mucosa. The results of this study depict the strong association of Helicobacter Pylori infection and dyspepsia.

\section{Conclusion}

In this study $69.3 \%$ of the patients examined were $\mathrm{H}$. Pylori positive on histopathology. Male sex, older age ( $>$ 30 years) and duration of dyspepsia ( $>1$ year) are independent risk factor of $\mathrm{H}$. Pylori infection in dyspeptic patients.

\section{Acknowledgement}

We would like to acknowledge faculty of Ziauddin Hospital, North Campus for helping us during the study, staff for helping in data collection and all others who have given their input.

\section{References}

[1] Atherton JC, Blaser MJ, Coadaptation of Helicobacter Pylori and humans: Ancient history, modern implications. J, Clin, Invest. 2009; 119.

[2] Fennerty MB. Helicobacter Pylori: why it still matters in 2005. Cleve Clin J Med. 2005; 72:1-21.

[3] Lehours P, Yilmaz O. Epidemiology of Helicobacter Pylori infection. Helicobacter. 2007; 12: 1-3.

[4] Lacy BE, Rosermore J. Helicobacter Pylori: ulcers and more: The beginning of an era. J Nutr. 2001; 131: 2789-93.

[5] Queralt N, Araujo R. Analysis of the survival of H. Pylori within a Laboratory based aquatic model system using molecular and classical Techniques. Microb, Ecol. 2007; 54: 771-7.

[6] Khan SS, Zulfiqar A, Danish KF, Sauwal M, Bashir S, Zaman S. Prevalence of $\mathrm{H}$. Pylori infection in patients with gastroduodenal disease in Pakistan. In Railway Hospital, Rawalpindi. Rawal Med J. 2008; 33: 88-9.

[7] Ferrucci PF, Zucca E. Primary gastric lymphoma pathogenesis and treatment: what has changed over the past 10 years? $\mathrm{Br} \mathrm{J}$ Haematol. 2007; 136: 521-38.

[8] Pasceri V, Patti G, Cammarota G, Pristipino C, Richichi G, Di Sciascio G. Virulent strains of Helicobacter Pylori and vascular diseases: a meta-analysis. Am Heart J. 2006; 151: 1215-22.

[9] Asahi A, Kuwana M, Suzuki H, Hibi T, Kawakami Y, Ikeda Y. Effects of a Helicobacter Pylori eradication regimen on 
antiplatelet autoantibody response in infected and uninfected patients with idiopathic thrombocytopenic purpura. Haematologica. 2006; 91: 1436-7.

[10] Concepts in the management of Helicobacter Pylori infection: the Maastricht III Consensus Report. Gut. 2007; 56: 772-81.

[11] Cutler AF. Testing for H. Pylori in clinical practice. Am J Med. 1996;100:35-41

[12] Hussain SR, Abbas Z. Presence of Helicobacter Pylori in dyspeptic patients with endoscopically normal stomach. Pak J Med Sci. 2007; 23: 335-9.

[13] Qasim A, O' Morain CA. Treatment of Helicobacter Pylori infection and factors influencing eradication. Aliment Pharmacol Ther. 2002.

[14] Ndububa DA, Agbakwuru AE, Adebayo RA, Olasode BJ, Olaomi $\mathrm{OO}$, Adeosun OA, et al. Upper gastrointestinal findings and incidence of Helicobacter Pylori infection among Nigerian patients with dyspepsia. West Afr J Med. 2001; 20: 140-5.

[15] Adesanya AA, Oluwatowoju IO, Oyedeji KS, da Rocha-Afodu JT, Coker AO, Afonja OA. Evaluation of a locally-made urease test for detecting Helicobacter Pylori infection. Niger Postgrad Med J. 2002; 9: 43-47.

[16] Ola SO, Yakubu A, Otegbayo JA, Oluwasola AO, Ogunbiyi JO, Akang EE et al. The most appropriate site for endoscopic biopsy for the detection of H. Pylori among Nigerians in Ibadan. West Afr J Med. 2006; 25: 269-72.

[17] Ahmed R. Management of dyspepsia.Pak J Med Sci 2004;20:5560

[18] Marshall BJ. Helicobacter Pylori. The etiologic agent for peptic ulcer. JAMA 1995;274:1064-6

[19] Athrton JC, Blaster MJ. Helicobacter infection. In: Favci AS, Brawnwald E, Wilson KG, Martin JB, Kasper DL, et al. Harrison's Principles of Internal Medicine 1998. p. 941-43.

[20] Brown KE, Peura DA. Diagnosis of Helicobacter Pylori.Am J Gastroentrol Clin North Am 1993; 22: 105-15.

[21] Gold Bd, Colletti RB, Abbot M, Cziknn SJ, Elistsur Y, Hassall E, et al. North Amereican Ssociekty for Pediatric Gastroenterologyand Nutriton. Helicobactere Pylori infection in children: Recommendations diagnosis and treatment. J Pediatr Gastroenterol Nutr 2000; 31: 490.

[22] Lacy BE, Rosemore J. Helicobacter Pylori: Ulcers and more: The beginning of an era. J Nutr 2001; 131: 2789-93.
[23] Dunn ED, Cohen H, Blaser MJ. Helicobacter Pylori. Clin Microbiol Rev 1997; 10: 720-41.

[24] Ibrahim BH, Anim JT, Sarkar C. Helicobacter Pylori associated chronic gastritis in Kuwait. Annals of Saudi Medicine 1995; 15: 570-4.

[25] Shennak MM, Kilani AF. Helicobacter Pylori in dyspeptic Jordanian patients. Trop Gastroenterol 1998; 19: 15-8.

[26] Bani-Hani KE, Hammouri SM. Prevalence of Helicobacter Pylori in Northern Jordan: Endoscopy based study. Saudi Med J 2001; 22: 843-7.

[27] Mohamed AE, Al-Karawi A, Al-Jumah A, Ahmed AM, Sharig S, Yasawy MI et al. Helicobacter Pylori: incidence and comparison of three diagnostic methods in 196 Saudi patients with dyspepsia. Hepatogastroenterology 1994; 41:48-50.

[28] Azim Mirghani YA, Ahmed S, Ahmed M, Ismail MO, Fedail SS, Kamel M et al. Detection of Helicobacter Pylori in endoscopic biopsies in Sudan. Trop Doct 1994;24:161-3

[29] Hashemi MR, Rahnavardi M, Bikdeli B, Dehghani Zahedani M. H Pylori infection among 1000 southern Iranian dyspeptic patients. World J Gastroenterol 2006; 12: 5479-82.

[30] Gunaid AA, Hassan NA, Murray-Lyon I. Prevalence and risk factors for Helicobacter Pylori infection among Yemeni dyspeptic patients. Saudi Med J 2003; 24: 512-7.

[31] Zaitoun AM. Histological study of chronic gastritis from the United Arab Emirates using the Sydney system of classifi cation. J Clin Pathol 1994; 47: 810-5.

[32] Britt DP, Barakat MH, Tungekar MF, Painchaud SM, Adlouni M, Kern K, Malhas L. Helicobacter Pylori in dyspeptic patients in Kuwait. J Clin Pathol 1990; 43: 987-91.

[33] Malik MF, Hussain T, Khan MN, Mirza SA, Faroo M Helicobacter Pylori infection in patients with dyspeptic symptoms having normal endoscopy. PAFMJ. 2010; 1. http://www.pafmj.org/showdetails.php?id=308\&t=o.

[34] Talib A, Shujai M, Mahmood K, Farooqui AN, Mustufa G. Various methods to detect helicobacter pylori and their respective yield. Ann Abbasi Shaheed Hosp Karachi Med Dent Coll. 2005; 10: 698-703.

[35] Inayatullah M, Arshad M, Nasir SA, Anjum AH, Hussain A. Occurrence of helicobacter pylori in patients presenting with dyspepsia. Pakistan J Gastroenterol 1993; 7: 74-7. 